\title{
Right answers and Realism: Ronald Dworkin's theory of integrity as a successor to Realism
}

\author{
STEPHEN W SMITH*
}

University of Birmingham

\section{Introduction}

O the extent that there is such a thing as American Jurisprudence, ${ }^{1}$ Legal Realism ${ }^{2}$ lies 1 close to its foundation. Several critical schools of thought (e.g. Critical Legal Studies (CLS)) have claimed they are the progeny of Realism. ${ }^{3}$ Other, more scientifically based schools, such as jurimetrics or the law and economics movement, are believed to derive from central claims of Legal Realism. ${ }^{4}$ Other scholars, for example Brian Leiter, claim to continue to follow its tenets even if the version has been reinterpreted. ${ }^{5}$ Legal Realism, then, accounts for the beginnings of a number of distinctly American legal theories. However, one of the most recognised American theories - Ronald Dworkin's law as integrity - does not make similar statements. Dworkin has never claimed Legal Realism as an influence although he is aware of its theories and has engaged with them. ${ }^{6}$ Indeed, Dworkin and Legal Realism are rarely treated together at all. ${ }^{7}$ To the extent that they are, they are often put on polar opposites specifically in relation to the indeterminacy of legal rules. In fact, Leiter has gone so far as to claim Dworkin's view is a 'sophisticated' view of Formalism. ${ }^{8}$

This article will contest that view. It will argue that Dworkin's theory of integrity follows on from the important tenets of Legal Realism. His theory of constructive interpretation,

* I would like to thank Gavin Byrne, Sean Coyle, James Lee, Sheelagh McGuinness, Frederick Schauer and Gordon Woodman for helpful comments on earlier drafts of this article. All the usual disclaimers apply.

1 N Duxbury, Patterns of American Jurisprudence (Clarendon Press 1995). For an opposing view, see B Leiter, 'Is there an "American” Jurisprudence' (1997) 17 OJLS 367-87 reprinted in B Leiter, Naturalizing Jurisprudence (Oxford University Press 2007) 81-102.

2 There is, of course, a Scandinavian Legal Realism in addition to the American version. However, the Scandinavian version is not one I will consider further. Thus, any reference to Legal Realism or Realism should be taken to mean exclusively American Legal Realism.

3 A Altman, 'Legal Realism, Critical Legal Studies, and Dworkin' (1986) 15 Philosophy and Public Affairs 205-35, 207.

4 Leiter (n 1) 95-6. But see, Duxbury (n 1) ch 5 for an alternative view.

5 Leiter (n 1) 21.

6 Pragmatism, as he calls it in Law's Empire, appears to be a form of Legal Realism as an interpretive theory: R Dworkin, Law's Empire (Belknap Press 1986) 151-64.

7 Frederick Schauer, however, has recently suggested that Dworkin and the Realists are likely to reach similar decisions in practice: F Schauer, 'Legal Realism Untamed' (2013) 91 Texas Law Review 749.

8 B Leiter, 'Legal Formalism and Legal Realism: What is the Issue?' (2010) 16 Legal Theory 111-33, 112. 
while it builds upon and develops important Realist themes, requires a fundamental acceptance of some of its major conclusions. I wish to be clear what the claim entails. I am not suggesting that Ronald Dworkin is a Realist. He is not. Nevertheless, I will argue Dworkin and the Realists would find common ground in a number of important concepts. These concepts were important central tenets of Realism which Dworkin, explicitly or otherwise, has accepted and play foundational roles in his theory of law as integrity. There are crucial aspects where he deviates from Realism but Dworkin and the Realists have more in common than most think. It should also be made clear that this article will not present the claim that if one starts out with a Realist position, then one must end up with Dworkin's theory of integrity. It does not. The claim being made here is a more limited one. Dworkin's theory of law as integrity is one possible conclusion which can be reached from Realist premises. It is not the only possibility and nothing I say here should detract from the suggestions about other theorists like Leiter or those in the Critical Legal Studies movement that their theories are based upon Legal Realism. Realism is a broad church and while CLS and Leiter can rightly claim to be successors to the Realists, Dworkin could likewise claim inspiration from their views should he wish to do so.

To explore these connections it becomes necessary to determine what the central tenets of Realism are. This has never been an easy task as the Realists did not all derive their inspiration from one central source material nor did they all believe or argue the same sorts of things. ${ }^{9}$ It covers everything from the strict behavioural account of legal practice used by Underhill Moore, to the sociological account utilised by Karl Llewellyn, to the Freudian psychology-based approach championed by Jerome Frank. ${ }^{10}$ They did not always agree on everything and even major points of criticism of others applied as much to colleagues within the Realist camp as they did to those outside. ${ }^{11}$ Despite this, there are some things which the Realists had in common and the first task of this article will be to explore those central ideas. This will be the focus of Part 2 of the article. Part 3 will then go on to explore some of the important theoretical questions which are raised by the Realists but which they never completely address. Part 4 will then examine how Dworkin's theory of integrity answers some of these resulting issues. The final section will examine what this means for our understandings of both Dworkin's theory as well as American Legal Realism.

\section{Central tenets of American Legal Realism}

As noted above, determining the central tenets of American Legal Realism is difficult. Due to the varied interests of those within the camp of American Legal Realism, it can be hard to credit anything as an actual central tenet. Underhill Moore, for example, seemed to spend a large majority of his time involved in describing behaviour which was some way related to legal rules. ${ }^{12}$ Frank spent most of his time discussing either fact scepticism or the psychological implications of the law. ${ }^{13}$ Others had similarly narrow interests even if some of them were more legal in origin.

Karl Llewellyn, however, did indicate that there were a number of characteristics of all Realists. He argued that they shared a number of things in common which he sets out in

9 Duxbury (n 1) 68.

10 Leiter (n 1) 16, 28-29.

11 Duxbury (n 1) 69; K Llewellyn, 'Some Realism about Realism: A Response to Dean Pound' (1930-1931) 44 Harvard Law Review 1222-64, 1233-34.

12 U Moore and C C Callahan, 'Law and Learning Theory: A Study in Legal Control' (1943) 53 Yale Law Journal $1-136$.

13 J Frank, Law and the Modern Mind (Peter Smith 1970; original publication 1930); J Frank, Courts on Trial (Princeton University Press 1949). 
'Some Realism about Realism' but only five of the nine suggested tenets are 'characteristic marks' of Realist scholars. ${ }^{14}$ Those five are the following:

1 'the temporary divorce of "Is" and "Ought" for purposes of study";

2 ... 'a distrust of the theory that traditional prescriptive rule-formulations are the heavily operative factor in producing court decisions';

3 'the belief in the worthwhileness of grouping cases and legal situations into narrower categories than has been the practice in the past';

4 'An insistence on evaluation of any part of law in terms of its effects, and an insistence on the worthwhileness of trying to find these effects'; and

5 'an insistence on sustained and programmatic attack on the problems of law along any of these lines'. ${ }^{15}$

Brian Leiter has likewise argued that there are central tenets of American Legal Realism. Leiter argues the 'Core Claim' of Realism is that 'judges respond primarily to the stimulus of facts.' ${ }^{16}$ Leiter wants to draw particular attention to the word 'primarily'. He highlights that the Realists did not claim that rules were irrelevant to a judicial decision but that the main thrust of any judicial decision is what appears to be most fair under the factual circumstances of the case. ${ }^{17}$ This Core Claim is further bolstered by what Leiter refers to as the Determination Thesis and the Generality Thesis. ${ }^{18}$ The end result of this is that Realists, according to Leiter, are proponents of the following:

(1) a descriptive theory about the nature of judicial decision, according to which,

(2) judicial decisions fall into (sociologically) determined patterns, in which (3)

judges reach results based on a (generally shared) response to the underlying facts of the case, which (4) they then rationalize after-the-fact with appropriate legal rules and reasons. ${ }^{19}$

Taking what both Llewellyn and Leiter state together, general themes emerge which form a basis of any claims about Realism. First, Realism is particularly interested in judicial decision-making. That is not its only focus but it does have an emphasis on that part of the law. Furthermore, Realists were specifically concerned with the ability to be able to predict judicial decisions. They wanted the ability to be able to know in advance the likely result of cases which came before the courts. Consequently, they have a specific focus on practical lawyering. In other words, the Realists' prime concern was not philosophical matters but legal ones. A result which was philosophically unsound would still have been a useful one, from their position, provided it was legally helpful.

In addition to this emphasis on practical lawyering, prediction and judicial decisionmaking, the Realists were also keen to explore the use of additional material (usually from social sciences) beyond the commonly accepted legal sources. ${ }^{20}$ This had two implications.

14 Llewellyn (n. 11) 1238.

15 Ibid $1236-38$.

16 Leiter (n 1) 21.

17 Ibid.

18 Ibid 26. The Determination Thesis is that 'choice of decision must, in fact, be sufficiently fettered so that prediction is possible'. The Generality Thesis is that 'these fetters upon choice must not be idiosyncratic facts about individual judges, but rather must be of sufficient generality or commonality to be both accessible and to admit the sorts of lawful generalizations that make prediction possible'.

19 Leiter (n 1) 30.

20 Not all of their efforts to increase the ability to accurately predict results relied, however, on the use of social science. For example, Llewellyn spent a considerable amount of time focusing on the difference between 'paper rules' and 'real rules': K Llewellyn, 'A Realistic Jurisprudence: The Next Step' (1930) 30 Columbia Law Review 447-53. 
First, the Realists used these additional materials to aid and bolster the prediction enterprise. They thought that these additional materials could provide them with an ability to better predict the results of cases before the courts. They did not always agree on what materials were best placed to help in that regard but they did broaden the use of materials beyond those which had previously been used. Moreover, they found that additional materials provided further methods to evaluate and assess the law. This provided a benefit to the Realist movement because they wanted to explore not only the way the law worked but also how to make it work more effectively. The use of these broader materials allowed not only the prediction project to progress but also provided a needed constructive way to evaluate the law. It meant that the Realists had a much more inclusive idea as to what was relevant for law than previous jurisprudential theorists might have done.

One additional theme of Realism was the indeterminacy of legal rules. This theme developed from the broad themes discussed in the previous two paragraphs. While a focus on prediction or the use of social science research in exploring the law are methodological themes, the indeterminacy of legal rules is different. Instead of being about the methods used by the Realists, the idea that the standard written rules did not always determine the outcome in (at least some) concrete cases was a conclusion reached because of those approaches. ${ }^{21}$ Even so, it is one of the themes of Realism which is most likely to get distorted in discussion. Some have argued that the claim attributed to the Realists is overstated. The claim made is that the Realists argued that the law was globally indeterminate. Leiter argues that the Realists' claims were only locally indeterminate and, in particular, limited to those cases which came before the courts. ${ }^{22}$ Whether or not this is an accurate statement of the Realist position, the Realists did claim that cases were pervasively indeterminate even if not globally so. ${ }^{23}$ A comparison helps to illustrate this point. H L A Hart argued that indeterminacy in law was only in cases of 'open texture'. 24 The law was subject to open texture because we are not clear about language. Words that we use have a 'core of certainty' and a 'penumbra of doubt'. ${ }^{25}$ The 'core of certainty' consisted of those referents of a word which everyone agreed were contained within the definition. The 'penumbra of doubt' affected those cases where it was not clear if the word in question covered them or not. In his seminal example, Hart argued that a car would fit within the 'core of certainty' of the word 'vehicle'; a bicycle or skateboard, on the other hand, were less clear and covered by the 'penumbra of doubt'. ${ }^{26}$ For Hart, these cases occurred because we were not always specific enough about our use of language. ${ }^{27}$ In addition, we were bad at predicting the future and thus new information was rarely covered explicitly in a rule. ${ }^{28}$

The Realists did not believe that indeterminacy claims were so limited. They would have argued that Hart's 'open texture' was only part of the picture. Facts could often be indeterminate in the sense that they were filtered through witnesses' or judges' perceptions

21 Schauer (n 7). It should be noted the difference between particularism (the idea that a case is determined by factors unique to that case and therefore each decision is individualistic) and the view that factors outside the specified rules might determine the outcome in cases. The second view need not be particularistic if there is a pattern to those decisions even if that pattern involves factors outside of legal reasons as we generally conceive them. The Realists tended to take the latter view even if they are often believed to be proponents of particularism. See ibid.

22 Leiter (n 1).

23 Schauer (n 7).

24 H L A Hart, The Concept of Law (2nd edn, Clarendon Press 1994) 123, 128-36.

25 Ibid 123.

26 Ibid 128-29.

27 Ibid.

28 Ibid. 
of importance and thus important information might be misremembered or valued differently by a judge. ${ }^{29}$ There were also a number of rules which could potentially be in play in a particular case and the judges determined which rule applied and why it did so. ${ }^{30}$ Additionally, a judge might read cases differently from her predecessors and apply rules in a different manner. ${ }^{31}$ Finally, there might be cases where judges applied rules only after they had reached a decision on other grounds and the rules therefore only played a post hoc justificatory role. ${ }^{32}$ To the Realists, judicial decision-making was a complex activity and the prediction of it included not only an understanding of the language used in the rule but of surrounding factors, all of which might affect the ability of the rule to determine the outcome in a concrete case.

Two examples highlight the distinction between the two positions. Those two cases are Brown $v$ Board of Education, ${ }^{33}$ the famous US Supreme Court case on the desegregation of schools, and $\mathrm{R} v \mathrm{R},{ }^{34}$ the UK criminal case which outlawed the marital rape exception. ${ }^{35}$ Both cases are indeterminate as the rule set down in previous cases was not followed. ${ }^{36}$ Indeed, both cases overruled the pre-existing legal rule - Brown overruled Plessy $v$ Ferguson ${ }^{37}$ and $R v R$ overruled, among others, $R v$ Clarence. ${ }^{38}$ Neither decision involves what Hart referred to as open texture. Brown was covered by the 'separate but equal' doctrine set down in Plessy. $\mathrm{R} v \mathrm{R}$ fits within the rule in Clarence. Nor is it a case where the facts in the subsequent cases (Brown, $\mathrm{R} v \mathrm{R}$ ) were not envisaged at the time of the previous cases (Plessy, Clarence). $\mathrm{R} v \mathrm{R}$ is the same sort of case as Clarence on this issue. ${ }^{39}$ While Plessy dealt with railroad cars and not education systems (as Brown did), educational systems were around during that time and the language of Plessy is broad enough to cover any societal arrangement. ${ }^{40}$ They are not cases based upon our inability to see the future like

29 Frank (n 13).

30 K Llewellyn, 'Remarks on the Theory of Appellate Decision and the Rules or Canons about How Statutes Are to be Construed' (1950) 3 Vanderbilt Law Review 395.

31 K Llewellyn, The Bramble Bush (Oceana Publications 1951) 180.

32 Leiter (n 1) 30.

33 (1954) 347 US 483.

34 [1992] 1 AC 599.

35 The marital rape exception was a rule in UK criminal law that a wife, by virtue of getting married, had consented to all physical intercourse. It was therefore not legally possible for a husband to rape his wife: ibid 603-04. The genesis of the exception appears to be Sir Matthew Hale's History of the Pleas of the Crown (1736): ibid 604 .

36 The same claim could be made about Riggs v Palmer 115 NY 506, 22 NE 188 (1889), the case famously used as an example by Ronald Dworkin (n 6) 15-20. The wills statute at issue in that case appears to be relatively clear on point. However, because the case is linked so readily to Dworkin's views on integrity and the law, other cases provide a better test for exploration for our purposes.

37 (1896) 163 US 537.

38 (1888) 22 QBD 23.

$39 \mathrm{R} v \mathrm{R}$ ( $\mathrm{n}$ 34) is certainly a clearer case of the marital rape exception. Clarence (n 38) dealt with a wife who had developed a sexually transmitted disease (STD) from intercourse with her husband who, while knowing he had the disease, did not inform his wife. The argument was that the fact that he had an STD but had not disclosed it vitiated the consent his wife had given to sexual relations. The court ruled that was not possible since, at least in part, she had consented to the marriage and that meant, necessarily, that she had consented to any and all sexual contact.

40 Plessy v Ferguson (n 37) 544. The Supreme Court specifically mentions schools noting: 'The most common instance of this is connected with the establishment of separate schools for white and colored children, which has been held to be a valid exercise of the legislative power even by courts of States where the political rights of the colored race have been longest and most earnestly enforced.': ibid. At several points, the Supreme Court uses the argument that, since it is acceptable in education to separate out the races (relying heavily on the fact that the DC School District was segregated), then it must be acceptable for train companies to do the same: ibid 544-45, 545, 551. 
determining a case raising the question of whether a Segway fits into Hart's 1960s statute prohibiting vehicles in the park. Furthermore, in neither case does the court rely on language to change the applicable rule but overrule the previous decision.

What is particularly interesting about these two cases is that it would have been possible to make a case relying on Hartian open texture for the decision. The court in Brown could have argued that the Topeka School Board needed to bus black students to the 'white' school merely because they had failed to satisfy Plessy's 'separate but equal' test. ${ }^{41}$ In general, the facilities provided to black students did not fit under the standard definition of equal if equal means something beyond merely providing something within the same class to different groups. ${ }^{42}$ They could have argued instead that equal meant that the facilities had to be of the same standard. Likewise, in $R v R$, the married couple had separated prior to the rape in question and the woman lived in a different house from the husband at the time of the rape. ${ }^{43}$ The court could have argued that the marital rape exception did not apply under the circumstances as the separation had changed the applicable rule. ${ }^{44}$ In neither case did the court in question take this way out. Instead, they argued that subsequent legal principles had made the previous rule unsound (if it had ever been sound) and the previous decisions were overruled. ${ }^{45}$

It is this sort of case that the Realists want to explore. Ambiguity of language is an important aspect of the law, but cases in which the court reaches a decision which does not follow clearly from previous decisions for other reasons are also worthy of consideration. To the Realists, this was all part of the same indeterminacy problem. In their thinking, there were a multitude of reasons why decisions might be unclear and we needed a comprehensive method for exploring the relevant issues. The Realists, unlike Hart, conceived of legal indeterminacy as being a broad practice involving a number of different factors all of which could potentially be applicable in a given case. They considered this all part of one process involved in judicial decision-making. So, Hart probably would have had a response to the issues created by Brown and $R v R$. They just would not have been covered by his conception of open texture. To the Realists, however, all of these sorts of issues were contained within the heading of legal indeterminacy.

In conclusion, we can state there are a number of important things we might find as indicative of the Realist position. They were particularly focused on practical lawyering as

41 Indeed, the lower court decisions in Brown involve four separate school districts (Topeka, Kansas; Clarendon County, South Carolina; Prince Edward County, Virginia; and New Castle County, Delaware) and there was an examination of whether those School Districts did provide 'equal' treatment: (n 33) 486. In the cases themselves, the Kansas schools were considered to be equal but those in South Carolina, Virginia and Delaware were not. According to Chief Justice Earl Warren (who wrote the opinion of the Court), equalisation measures had either been completed or were 'well on their way' by the time of the Court's decision: ibid 492.

42 As noted in $\mathrm{n} 41$, the four school districts in question might have been exceptions to the rule. Nevertheless, anyone wanting a visual representation of the extent to which 'separate but equal' wasn't really equal need only look at pictures of, for example, water fountains in the segregated South during this period.

43 See (n 34) 614-15.

44 The Court of Appeal, it should be pointed out, does consider this possibility. It had been used in previous cases to outline exceptions based upon the issuance of a decree nisi, express arrangement by the couple, or by court order. The Court of Appeal, however, decides instead that 'the law should declare that a rapist remains a rapist subject to the criminal law, irrespective of his relationship with his victim': ibid 611. There is discussion by both the Court of Appeal and the House of Lords as to the word 'unlawfully' in the Sexual Offences (Amendment) Act 1976, s 1(1): ibid 610-11, 623. In particular, the question that arises is whether the Act of 1976 enshrines the marital rape exception in the law such that it cannot be removed by the Court. That issue, then, is somewhat subsidiary to the question as to whether or not the marital rape exception is a valid exception in common law.

45 Brown (n 33) 494-95; R $v$ R (n 34) 623. 
well as judicial decision-making. This included the ability to be able to predict the decisions that judges and courts might make in disputes which came before them. They also looked to expand the number of relevant sources of information which were considered both in relation to legal decision-making as well as to the process of evaluating legal decisions. This included a complex notion of what constituted legal indeterminacy which was grounded in the notion of a broad, pervasive conception of when the rules could be indeterminate and what the causes of that indeterminacy were.

\section{Issues arising from Realism}

There are two main issues which are brought up by the Realist examination of the law but are not resolved by it. The first question is what constitutes legal reasons for actions. In other words, what is encompassed by the word law? This is a standard question in legal philosophy but it takes on a special importance for the Realist project. Because of Realists' understanding of legal indeterminacy and their acknowledgment of the expanding class of available reasons for action, they cannot identify the distinction between legal and non-legal reasons by reference to the job performed by those reasons. Both types can provide reasons for legal decision-making. We could determine that something is a legal reason for action by looking to its source, but that also provides difficulties for the Realists. Since legal decisions are likely sources of law and the reasons for those decisions need not necessarily be lawrelated reasons, the Realists would need to explain how the action of a judge speaking or writing turned a non-legal reason into a legal one. Again, the easy answer (that the act of speaking or writing by a judge creates a legal reason for action) would not likely work. Not everything a judge speaks or writes would work as a legal reason (for example, a letter written to a friend). Even if it were limited to those times when a judge was specifically acting as a judge, this argument would not be particularly effective. If a judge stated that they had decided a particular decision by flipping a coin, the legal community would not see that as a legal reason for the decision even if the judge had, in fact, decided by that method. There must be some further criteria for distinguishing between legal reasons for actions and those non-legal reasons. Additionally, the Realists would be required to hold that there is a distinction between certain reasons called legal and those which are not because the use of post hoc justifications which they frequently commented on requires it. If all reasons are potentially legal reasons for action, then there is nothing wrong with using 'non-legal' reasons as justification. It is only if non-legal actions are seen as unjustifiable reasons for decisions that judges need to rely on so-called 'legal' ones.

This classification issue has bite because of the more overarching question of justification. Any legal system must provide reasons for individuals to abide by it if that legal system is going to continue to exist. We must accept those decisions made by those acting under legal authority as binding. This causes particular problems for Realists because of the varied influences on legal decision-making. There must be an explanation why a decision taken by a judge based on extra-legal factors provides a sufficient reason for holding that (1) we are required to follow that decision, and (2) society is entitled to believe that we will follow the decision. The argument in support of the legitimacy of law is easy to make in situations where the grounds for our legal decisions are limited to legal reasons for action. If judges could only make decisions based upon previous case-law and statutes, authority for such decisions is on the basis of the existing rules - for example, that they offer fair warning of likely legal consequences, that they have been subject to democratic review or that they are authorised by a social contract. However, if the Realist critique is accurate, then decisions are being made for reasons which have not been previously agreed, are not vetted in the public sphere and are, at least sometimes, hidden from view. Such decisions are ones 
we would consider suspect in terms of legitimacy and justification. Since these decisions are extra-legal in that they do not rely on legal reasons for action, then even if the overall legal system is justified, these particular decisions may not be.

We can explore this by way of example. Suppose we had Holmes' famous 'bad man'. 46 Let us further suppose that our bad man lives in the community covered by Hart's 'no vehicles in the park'. ${ }^{47}$ Our bad man wishes to bring a bicycle into the park but does not want to suffer any adverse legal consequences for doing so. Bicycles have been allowed in the park before. However, they were children's bicycles and our bad man wants to bring in a heavy-duty mountain bike so he can train for an upcoming race. The bad man examines all of the information related to the regulation and decides that, since bicycles have been allowed in the past, he is likely to be allowed to use his bicycle as well. To his surprise, when he brings his bicycle into the park, he is cited for violating the regulation. When he contests this decision in court, he is told by the judge that he cannot bring a bicycle into the park as it is a vehicle. In particular, the judge relies on safety arguments to argue that the legislative body in question meant to include bicycles within the definition of vehicle. This is over the protestations of the bad man who, having looked through the law in question and the cases interpreting it, asserts that no previous decision has made any mention of 'safety' when determining the definition of vehicle under the rule.

Under this scenario, why should our bad man feel that the judge's decision is a legitimate legal decision? We could fall back on the argument that if he fails to abide by the decision, he is subject to sanctions (e.g. a fine) and if he fails to comply with the sanctions, further more powerful sanctions might be applied (e.g. incarceration). That does not necessarily provide a justification for the decision; it merely coerces our bad man to accept it. If we do not rely on coercion (for example, if we want to argue that the decision should be considered right or proper), we need to look somewhere else. Nor would it be useful to argue that the Realists did not concern themselves overmuch with this justification problem. ${ }^{48}$ Even if they did not care about legitimacy and justification, nothing prevents us from asking the question in relation to their theory.

Additionally, if the Realist critique is accurate, we need some justification for the system as a whole or at least the way the system is run. Why would we design a system which allows judges to make decisions based upon non-legal factors? Could we not develop some sort of mechanistic system for determining answers in cases other than Hart's open texture ones? Could we not require that our legislatures be more specific when developing statutes? Alternatively, could we not construct a rule when anything which is not specifically prohibited is excluded from regulation? To put the questions another way, why do we persist with the legal system we have? Why do we put such power into the hands of a few individuals, often ones who are neither representative of the population at large nor democratically elected? In order to justify the legal system as a whole we need some semblance of an answer to these sorts of questions. Moreover, these questions persist even if we are only interested in a purely descriptive account of the law. We must still have some understanding as to why individuals within a system feel bound by it. We must understand why it is that they feel an obligation (using Hart's terminology) ${ }^{49}$ to obey the law despite

46 O W Holmes, 'The Path of the Law' (1897) 10 Harvard Law Review 457, 460-61.

47 Hart (n 24) 128-29.

48 Leiter (n 1) 114-15.

49 Hart (n 24) 6-7. 
misgivings we might have about the way the system operates. ${ }^{50}$ We must also have an explanation for why individuals continue to abide by the law even when it is against their interests to do so. We must further explain why judges, when acting in their official capacity, act as if they can provide justifications for their actions and expect that these will be accepted as right and proper ones. We must understand why it is that judges continue to couch their decisions in legal language and legal reasons even if, at least some of the time, the answer they give is not truly why they decided as they did.

Realism does not really give us answers to these questions. The Realists provide us with a reliable description of what is occurring in legal decision-making but cannot provide us with an answer as to why that ought to be the case. Even when they provide optimal ways of working within the system they do not tell us why the legal system needs to be in such a state as to require those optimal ways in the first place. We need to look elsewhere.

\section{Dworkin as an answer to Realist issues}

If Realism cannot provide us with an answer to these important questions, another theory can provide it without requiring that we abandon the conclusions from Realism that we wish to keep. Those looking for an answer to justificatory questions while still maintaining the basic tenets of Realism can look to Dworkin's law as integrity to provide them. In other words, Dworkin's theory is not incompatible with Realism.

It is worth beginning that discussion by examining the existing parallels between Realism and Dworkin's work. One fundamental parallel between the two is that both focus on judicial decision-making. The Realists, as mentioned above, paid particular attention to the role of judges, both at the trial court and at the appellate level. Dworkin, with the focus on law as integrity, Hercules and the right answer thesis, ${ }^{51}$ also focuses on the judicial aspect of law. ${ }^{52}$ This does not mean they exclusively focus on judicial decisions because neither does, but the judicial aspect of law is more important in their theories of law than, for example, it is in Austin, Kelsen or even Hart. Moreover, both focus on practical lawyering. Dworkin gives a special prominence to exploring the question of legal disputes and disagreement. ${ }^{53}$ This emphasises the question of how it is that legal professionals can disagree about the fundamental claims of a particular legal system. ${ }^{54}$ The question in its simplest form is a pragmatic one - how do we explain legal disagreement? Dworkin and the Realists pay attention to such questions even if other legal theorists like Austin, Kelsen and Hart do not. Additionally, Dworkin and the Realists often use case-law to provide examples of particular claims. ${ }^{55}$ Their purpose in doing so is to evaluate not only the theoretical basis of law, but to actually test whether that basis is correct. Both think they are providing a method by

50 We might, indeed, even question whether or not people actually feel an obligation to obey the law. This is presumably an empirical question (or could be an empirical question) but I am not aware of anyone who has ever explored it empirically. I am grateful to Frederick Schauer for bringing this point to my attention.

51 The extent to which Dworkin still maintains the relevant thesis as a 'right answer' thesis as opposed to a 'best answer' thesis is a bit murky. Many contend that Dworkin now talks about 'best answers' as opposed to 'right answers'. However, the most recent complete statement of his views on law (Justice in Robes (Belknap Press 2006)) still maintains at least some focus on 'right' answers and a 2006 book which explores his views makes repeated references to right answers, a characterisation he does not refute in his response: S Hershovitz (ed), Exploring Law's Empire: The Jurisprudence of Ronald Dworkin (Oxford University Press 2006). As best I can tell, then, Dworkin's view is still largely similar on point to the one he has always professed and any distinction between a 'right' answer and a 'best' one is semantic. Even if this is not true, I am not sure it changes any of the analysis in this article.

52 Dworkin (n 6) 14-15.

53 Ibid 6-7.

54 Ibid 3-6.

55 Ibid 15-30. 
which judges can explore their own legal decision-making, or to evaluate the real life decisions that judges make. Furthermore, both seek to expand the number of reasons available for evaluating the decisions of legal decision-makers, although the types of reasons are not the same. While the Realists looked to social science data, personal idiosyncrasies of the judges or other similar factors, Dworkin has focused his attention on principles. ${ }^{56}$ Thus, both look to increase the number of reasons found to explain legal decisions beyond legal rules, whether derived from statute or previous court decision.

These parallels between Dworkin's theory of integrity and Realism show the possibility of cross-germination between the two theories. However, it might be argued that these similarities are insufficient on their own and there is the very real question of legal indeterminacy to consider. While the Realists were keen to argue that the law was at least partially indeterminate, Dworkin has maintained that legal principles reduce the indeterminacy of law. ${ }^{57}$ Some might argue that, despite any initial facial likenesses between the two theories, the essential claim about indeterminacy creates an insurmountable barrier between the two. A deeper analysis reveals this is not the case. While Dworkin does argue that integrity minimises (if not completely eliminates) a multitude of answers to a particular legal question, this is not because of a fundamental disagreement with the Realist project as such. Dworkin must initially hold something close to the Realist conclusion on indeterminacy for the argument for principles to have any meaning. At the very least, he must start from a position much closer to Realism than it is to Hart's notion of open texture.

In order to understand this, we must explore why Dworkin thinks principles are so important. For Dworkin, legal rules cannot account for a number of cases. They are too inflexible and too all or nothing to be able to adequately explain the complexity of legal decision-making. They cannot, for example, explain the decision of the US Supreme Court in Brown, one of the decisions he notes at the beginning of Law's Empire. ${ }^{58}$ Dworkin likewise sees 'hard cases' as being a more comprehensive phenomenon than Hart ever admits. ${ }^{59}$ For Hart, they are a small number of decisions; ${ }^{60}$ Dworkin, on the other hand, argues that hard cases are frequent in the law. ${ }^{61}$ Dworkin argues that there are similarities between lines of cases which are used to bring disparate legal issues together in order to provide a means for resolving these cases. Those connections are what he calls principles. Brown, consequently, can be explained as a decision about something larger than the inflexible legal rules associated with previous cases like Plessy. It is a discussion of equality, a connection between a number of different sorts of cases so that the decision in Brown fits into the larger legal system. ${ }^{62}$ All of these disparate cases form a coherent system by being mutually supportive of each other.

Principles, then, are broad statements which express moral beliefs within a particular community. ${ }^{63}$ They apply across a range of cases and interact with other principles as well as legal rules in order to provide the most convincing legal arrangement possible under the circumstances. ${ }^{64}$ This idea of principles is much more expansive than is necessary to deal

56 R Dworkin, Taking Rights Seriously (Gerald Duckworth \& Co 1977).

57 Dworkin (n 6).

58 Ibid 29-30.

59 For example, he states that any case from any case textbook would provide examples of the principles he is talking about. See e.g. Dworkin (n 56) 23.

60 Hart (n 24) 154.

61 Dworkin (n 56) 81-130.

62 Dworkin (n 6) 379-92.

63 Dworkin (n 56) 82.

64 Ibid 81-130; Dworkin (n 6) 95-96. 
with uncertainty in a Hartian 'open texture' sense. If the only type of indeterminacy was based upon the penumbra of doubt, it is unnecessary to consider broad principles which apply to a large range of cases and bind the system together. There would be no need to go through that process in a majority of cases so the principles themselves would be superfluous. However, if the indeterminacy that Dworkin is considering is the pervasive one used by the Realists, then principles become a more reasonable idea. If almost any case might be subject to indeterminacy based upon the facts, a disparate collection of rules, or other factors, then moral principles which bind the legal system into a coherent whole become necessary. In other words, there is no reason to have a broad principle to explain whether a bicycle is a vehicle or not under a simple regulation prohibiting vehicles in the park. We do need principles to explain decisions such as Brown and $R v R$. Dworkin must start from a position that the pervasive indeterminacy of the Realists is a more accurate assessment of legal decision-making than the more limited notion of 'open texture' presented by Hart since it is only a more pervasive and comprehensive indeterminacy which requires the use of principles in the way that Dworkin uses them. The pervasive legal indeterminacy of the Realists is not therefore an anathema to the Dworkinian use of principles, it is a precursor to it. The Realists' ideas about indeterminacy provide support for an important presumption Dworkin makes about the law. As a result, it does not adversely affect the ability to see connections between the two sets of theories but supplements the similarities which have already been discussed.

With this understanding, it becomes possible to explain how Dworkin's law as integrity can plug the justification gap left by the Realist critique of law. That way is the right answer thesis that Dworkin provides. ${ }^{65}$ To explain this, let us return to our bad man wanting to bring a bicycle into the park. Our bad man brought a bicycle into a park covered by a rule which stated that 'no vehicles were allowed in the park'. Having explored the statute and previous case-law, our bad man had determined that there was no specific part of the legislation which prohibited bicycles per se nor was there any case-law which prohibited bicycles. Despite this, when the case came before a judge, it was determined by that judge that bicycles were included within the definition of 'vehicle' such that bringing one into the park constituted a violation of the law. Let us suppose, however, that the jurisdiction in question is slightly different from ours in terms of procedure. The law is exactly the same but litigants have the possibility after the court has made a decision to question it. Once a decision has been handed down, the judge must discuss that decision with the parties in question should they wish to do so. Our bad man requests such a discussion with the judge and asks why the court ruled the way it did despite the fact that there was no specific mention of prohibiting bicycles either in the legislation itself or in the previous case-law. Our judge has several responses available to her. She could reiterate the safety concerns which formed the essential part of the judgment itself. This will not provide much help. Our bad man will ask where these safety concerns came from since they did not appear in either the statute or previous case-law. What our judge will need to do is to provide a reason as to why those safety concerns could be used to make a decision, even if they were not specifically noted in the law before this case.

Note that the use of the Hartian response to our bad man will not be an effective mechanism. If our judge argues that there is a penumbra of doubt about the word vehicle and that she exercised her discretion in order to determine that 'bicycle' was covered, this will lead to serious problems with our bad man. He will argue that this exceeded her authority (since she should only act on the basis of the law, not on her 'discretion'). Even if

65 Dworkin (n 51) 41-43. Again, I do not think this analysis changes if we consider Dworkin to now hold a 'best' answer thesis as opposed to a 'right' answer one. See n 51. 
he does not do that, he will ask why she exercised her discretion in this particular way. Why, he might ask, did she exercise her discretion in order to find him guilty of violating the law instead of using her discretion in order to find him not-guilty? Our judge needs an answer to this question in order to satisfy the bad man and one that does not circle back to the safety concerns. If our judge answers 'Because I thought the safety concerns were important,' this only leads back to the same questions as to why the judge was entitled to consider them in the first place. Alternatively, the judge could fall back on claims of authority. She could claim that she was entitled to decide the way she did because that is the job she has been given by our legal system. The decision is authorised by the position she holds. That also would not find the support of our bad man. He will argue in response that the mere fact that her position gives her the authority to make decisions in the legal system does not mean that authority is unfettered. She would not, for example, be able to sentence him to death or public flogging for breaking the statute in question. Such a decision on her part would be an abuse of power. Why then, is her decision not a similar abuse of power, again because there is no specific indication that bicycles are covered? In other words, even if our bad man accepts that her role as judge provides her with the authority to make decisions generally, it does not follow that it justifies this decision in this case. Moreover, neither argument will necessarily prevent our bad man from bringing his bicycle into the park on subsequent occasions. Both justifications - the Hartian open texture one or the one based upon her authority as judge - can be seen as being personal to the specific judge. Our bad man, then, may decide in subsequent cases to try his luck with different judges. ${ }^{66}$ While our first judge might decide that bicycles are covered, the second (and third, etc.) may not.

If our judge wants to assuage the bad man, she needs to convince him that the decision she made was the correct one, despite what he perceives to be a lack of grounding for it. In order to do that, our judge is going to have to provide evidence that safety concerns are valid even if they are not specifically stated in the statute or covered by previous case-law. One way to do that will be to show our bad man that other courts have used safety concerns before in a range of cases, even where there was not a previous statement about safety in case-law or statute. While that is an important part, it is not the only part. She will further need to explain why this case is similar enough to other cases where safety has been an issue for it to be an acceptable reason for the decision here. She would further have to argue why, even if there are alternative possible justifications for decisions, the one she has chosen is the best one to have used under the circumstances. Notice that she cannot simply claim that her decision is one of a range of possible alternatives. She cannot simply claim that her decision is based upon a reasoned argument but that there were alternatives which were just as likely. Our bad man will simply insist she justify why she did not choose one of those other alternatives which would allow him to bring his bicycle into the park. She must claim that her decision is right or correct or best under the circumstances. That does not mean that she cannot accept that our bad man has made a reasoned and reasonable argument. She must have to claim, however, that hers is better than all alternatives. Moreover, she needs to claim that her decision is not just right or best in her opinion but right objectively. Her claim also has to be stronger than a claim of preference on her part for the argument she has given. If she merely claims a preference, then our bad man will simply query why her

66 This is the concern with particularism in relation to judicial decisions. If we cannot presume that the decisions have some sort of general application, then there is nothing to prevent an individual from attempting an action which brought a sanction in an initial case to try again. This point will be considered more fully in Section 5 . 
preference is better than his - why it is entitled to greater weight. ${ }^{67}$ If she cannot, then it simply becomes a claim about taste much like someone's preference for baseball over football. If she wishes to justify her decision, she needs to be able to state to the bad man that her decision is best not only for her, but for everyone. It must be an objectively true statement of the law.

What has been described, though, is no different than Dworkin's right answer thesis. He makes the following statement of the right answer thesis:

It is a claim made within legal practice rather than at some supposedly removed, external philosophical level. I ask whether, in the ordinary sense in which lawyers might say this, it is ever sound or correct or accurate to say, about some hard case, that the law, properly interpreted, is for the plaintiff (or for the defendant.). ${ }^{68}$

He further states:

Have you yourself found any ordinary legal argument on balance the soundest, in any kind of hard case? Then you, too, have rejected the no-right-answer thesis I take to be the target of my own claim. ${ }^{69}$

Dworkin's thesis requires that judges be able to make decisions which are objectively right, which is what our judge has attempted to do in this case. Her decision, if she wants to be able to justify it to our bad man, must be a decision which she can claim to be right and to be right objectively. She must be able to claim this despite the fact that others might disagree. In other words, she can accept that others might come to a different conclusion but that those conclusions are not as good as hers despite the fact that they may be reasoned and reasonable arguments. None of this, however, requires a refutation of the indeterminacy thesis as the Realists conceived of it. In fact, it requires the indeterminacy thesis as a starting point. It must start from the idea that cases are indeterminate in the pervasive way the Realists discussed in order for the right answer thesis to have sufficient bite.

Additionally, this reasoning works in the more complex cases of judicial decisionmaking used in Brown and $R v R$. In both cases, the side which ultimately lost (the School District of Topeka, Kansas, in Brown and the husband in $R v R$ ) would have, given the opportunity, questioned the decisions given in their respective cases. Indeed, in their cases, they probably have a stronger argument than our bad man since there was actual case-law in their favour prior to their actions. In order to justify those decisions, the judges would have to use the right answer thesis to convince them. They would need to argue that the previous cases, despite being legal decisions which argued that their actions were acceptable, were not the best statement of the law. In order to do this, they would need to show that higher values (e.g. equality under the law) were the most crucial values at stake and those values required the decision that the judges made. They would have to argue that these were the correct decisions no matter which judge made them even though previous judges had, in effect, gotten it wrong. ${ }^{70}$

67 It is possible that our judge will return to the argument about authority. However, the same problems would exist here as it does with the use of it earlier. Our bad man would argue that, even if she has general authority, it only exists in situations where she is acting appropriately. If she is exceeding her authority (as he would claim she is doing here), then it provides no greater justification for her decision now than it did before.

68 Dworkin (n 51) 41.

69 Ibid 42.

70 In making this claim, I do not want to forestall the idea that principles can change over time. It may be that a principle which was at one time valid has ceased to have validity and therefore decisions based upon that principle in the past are likewise invalid. That change, though, may be attributed to the creation of new, more important principles (or at least more important at the present time) and we would need a way to explain this. Moreover, even if principles lose their validity, we need some method for being able to explain to members 
Dworkin's theory of integrity, then, fills the justification gap which exists in the Realist explanation of the law without forcing one to refute many of the central claims of Realism. It also provides further benefits. First, it can help explain cases which the Realists have often had trouble with - those cases where the judge appears compelled to reach a decision despite being against it. Realist approaches to judicial decision-making suggest that judges often have enough flexibility to avoid reaching decisions which they find to be wrong. They ought to be able to manipulate precedents, the language in statutes, etc., so that they can reach a conclusion which they find satisfactory. That is not always the case. Sometimes judges reach decisions which they feel are compelled by previous case-law or statute even though they do not believe they are the right decisions on some other metric (e.g. morally, politically, or on policy grounds). Dworkin's theory can provide us with an answer to that question. Judges in these cases feel bound to reach the best decision in light of the previous law. Even if they personally disagree with the decision, a judge can come to a conclusion that a particular interpretation is the best legal answer in a specific case. One can decide that a particular answer is the best one, even if it is not personally a satisfactory one. ${ }^{71}$

\section{Conclusions}

In conclusion, there are still significant differences between law as integrity and Legal Realism. There are also a number of similarities and one need not give up all of the central tenets of either theory to accept that the other theory has benefits. For at least a couple of reasons, this answer might not be surprising. Dworkin does treat pragmatism less harshly than conventionalism. He claims that it 'so far from fitting our legal practices worse than conventionalism does, fits them better'. ${ }^{72}$ More relevant is Karl Llewellyn's approach to judicial decision-making which he terms 'Grand Style'. ${ }^{73}$ For Llewellyn, there were two types of judicial decision-making. The first, formal style, was a mechanistic way of making decisions involving only the logical extension of previous cases and nothing further - no further understanding of policy, principle or broader values. ${ }^{74}$ Grand Style, however, was expansive. It considered a broader range of materials including important issues of

[note 70 continued] of society why a principle, which was at one time valid, no longer is. So, even if the judge does not make the claim that previous judges made a wrong decision in a case, they must be able to explain why that decision would not be right now.

71 To provide a personal (admittedly anecdotal) example, I once worked for a trial court judge in Pennsylvania as a law clerk. One of the cases brought before the judge was a contract dispute involving the construction of a garage. The homeowners had contracted with a construction company for the construction of the garage to their specifications but were unhappy with the result and wished not to pay the amount owed. While their claims in contract had failed, their lawyer also relied on the Consumer Protection Law in Pennsylvania at the time. That law required that any sale involving a 'contact at the home' required that the purchasing party receive notice they had the right to rescind the contract within three days. If the notification was not provided at the time the initial contract was signed (which it is was not in this case), then the notification period began to run once the purchasing party became aware of the right to rescind (i.e. when their lawyer told them about it). 'Contact at the home' had been determined earlier by the appellate courts to include cases such as construction ones despite the purpose of the law being to deal with high-pressure door-to-door sales. Utilising the Consumer Protection Law, the homeowners then rescinded the contract. There was a provision within the statute that required the return of the items purchased but only if the selling party requested them within a set time period. Because the items in question were incapable of being returned, the attorney for the contractor did not request them back. At oral argument, the lawyer for the homeowners admitted that, if the materials had been requested, they would have been unable to provide them and the consumer protection ground would have failed. However, since they were not, they were simply not required to return them. While the judge I worked for thought the decision reached a dreadful result, the law did appear to require that he rule in favour of the homeowners and allow them to rescind the contract without having to 'return' the garage.

72 Dworkin (n 6) 157.

73 K Llewellyn, The Common Law Tradition: Deciding Appeals (Little, Brown \& Co 1960) 36-37.

74 Ibid 38 
principle. ${ }^{75}$ It further focused on the creation of good decisions on a large scale, even at the expense of static legal doctrine. ${ }^{76}$ The broad interpretive nature of Llewellyn's Grand Style is thus a forerunner to the interpretive method favoured by Dworkin. ${ }^{77}$ Llewellyn also often makes statements which appear similar to Dworkin's view on rules and principles. For example, in The Theory of Rules, Llewellyn argues for the use of the purposes of law in order to provide a more coherent basis for the law. ${ }^{78}$

He also prioritises the use of conceptions of justice and fairness, two of the foundational principles Dworkin deems important in the law. ${ }^{79}$ Llewellyn's view, thus, looks remarkably similar to Dworkin's views on integrity. He highlights the purposes of reasons as opposed to slavish dependence on written rules; the notion of change according to those purposes and reasons for rules and that it is these elements in the law, not written rules, which provide for the stability of the law. ${ }^{80}$ Llewellyn, consequently, appears to have a number of similar views to those expressed by Dworkin.

The real issue is what this might mean for our understanding of both Realism and law as integrity. One initial conclusion we can reach is that neither theory is quite as extreme as its detractors suggest. Realism has long been a frequent whipping boy for legal theorists because it is believed to be an over-exaggerated farcical theory about judges which lacks sufficient intellectual rigour. ${ }^{81}$ Dworkin has also been subject to criticism, particularly in relation to the right answer thesis as it too is considered an over-exaggerated position. ${ }^{82}$ However, neither theory need be understood in the extreme view. The acceptance of the Dworkinian view does not mean that one need accept that legal problems have solutions which are discernible like mathematical problems any more than one need accept that judicial decisions are based upon what the judge had for breakfast in order to accept Realism. Both positions are much more moderate than they may initially seem. Moreover, both focus on the important aspect of problem cases. While other theories have attempted to start with the areas in which there is convergence, both Realism and Dworkin appear to begin their analysis with cases of disagreement. Dworkin and Realism both seek to explain how it is possible for disagreement to exist in law instead of trying to explain our general agreement about the law. Realism and Dworkin provide a much more satisfactory view of those types of decisions as a consequence. We can further take from this the view that both theories see law as being part of a community. The law is not a separate institution which acts on its own without any input from the other important aspects of our lives. Law is

75 As Schauer notes, Llewellyn 'often stressed the role of the judge in seeking to reach, albeit in small steps, the best solution to a general social problem': Schauer (n 7). See also W Twining, Karl Llewellyn and the Realist Movement (Weidenfeld \& Nicolson 1973) 203-69.

76 Llewellyn (n 73) 36-37.

77 For a similar view in relation to Llewellyn's view of principles, see M D A Freeman, Lloyd's Introduction to Jurisprudence (8th edn, Sweet \&Maxwell 2008) 1016.

78 K Llewellyn, The Theory of Rules, F Schauer (ed) (University of Chicago Press 2011) 136-37. It is worth noting that, while Llewellyn argues against the use of 'principles' in this passage, his understanding of 'principle' is different to Dworkin's. He objects to principles used when 'it is to serve, and can claim to serve, as a basis for judgment not only independently of any countervailing authoritative and more explicit words, but also independently of any examination of its own underlying reason': ibid 136 (emphasis in original). For Dworkin, of course, any principle requires understanding an application of the underlying reason for the principle. It thus corresponds to what Llewellyn wants to be done with reasons - it requires by its formulation and in its formulation to give reason for it to be taken as the reason, and to persuade that there is reason for it to be taken as the reason': ibid 137 (emphasis in original).

79 Twining (n 75) 215.

80 Llewellyn (n 78) 142.

81 Leiter (n 1) 1.

82 Dworkin (n 51) 41-43. 
important because it incorporates, uses, evaluates and modifies the society and communities in which we live. We cannot explore and explain the law without coming to some understanding about what it is supposed to effect, both in terms of real life implications empirically as well as the underlying principles of the society in question. Law, then, is not a closed set, but one which necessarily involves a range of different factors.

Additionally, exploring how Realism and Dworkin's integrity can work together sharpens focus on the important elements involved in judicial decision-making. As has been noted above, Realism often suffers from criticisms about particularism. It is alleged that because the Realists viewed legal decisions as indeterminate, that meant they must believe that each individual decision was particular to the factual scenario. This, though, is a mischaracterisation and one that Dworkin helps to combat. If one sees indeterminism as a necessary ingredient of, first, Llewellyn's views on judging and, then, Dworkin's idea of law as integrity, it becomes clearer why indeterminism does not lead, necessarily, to claims about particularism. Understanding that the set of factual, legal and moral interactions which go into a judicial decisions are complex does not mean that prediction is not possible nor does it mean that general rules cannot be created from those decisions. Instead, it means that, in order to properly understand the reasoning behind those decisions, it is crucial to be able to grasp the entire picture. Some of those might be particularities about a particular judge - Lord Denning's noted bias towards the plight of elderly ladies is one example - but most involve aspects of judicial decisions which are normalised within the practice itself. These might be notions of fairness or justice which are outside of the strict legal rules; these might be biases or preconceptions which are implicit within the legal or more general community in which a specific court is situated.

Both Dworkin and the Realists, then, help us focus on what is really at the heart of problems about judicial decision-making. Decisions made by judges are difficult to understand jurisprudentially because of the wide power and scope implicit in the process. Judges are not (and indeed probably cannot) be bound by a mechanistic application of preexisting rules. If they could, we would have little reason to have people engaged in the practice instead of sophisticated computers which could sift through the legal statutes in an attempt to determine the most efficient legal outcome. That does not mean that we expect judges to be totally unfettered. What we expect is a balance between the strict legal rules and the flexibility needed in specific cases. Using Dworkin's theory of integrity and the Realist indeterminacy thesis allows us to explore in greater depth that balance.

Dworkin's theory of integrity can also help shore up the prediction programme that the Realists were so interested in. If Dworkin's view of the judicial decision-making is accurate, then the use of principles should make predicting what a judge will decide easier. If we know, for example, that judges will use safety measures because that is a significant concern within a society, then we would be able to predict that heavy-duty mountain bikes are unlikely to be brought into a park unless adequate precautions are taken. This will allow us to predict the use of these measures in cases, even if past case-law or statute does not specifically indicate their use. Prediction, as the Realists wanted, becomes a more systematic and easier process as a result.

Furthermore, if we understand where there are similarities we can then begin to focus on those differences which are truly at issue. There is still the considerable issue of determining the extent to which reasons for decisions which are not previous cases or statutes are considered legal. ${ }^{83}$ For Dworkin, reasons for actions which are used by judges (i.e. moral principles) are legal reasons. Indeed, Dworkin states that a judge, should she wish

83 Schauer (n 7). 
to be able to provide real justification for a decision, must use reasons which are legal. It is not possible for a judge to use a non-legal reason, or at least not use one and still provide a justifiable legal decision. Conversely, the Realists did not consider the additional reasons for action that judges used to be legal. Exploring this difference between the two theories might help us better understand the extent to which we must rely on 'legal' reasons for decisionmaking as well as the extent to which we can fruitfully have a single definition of 'legal'. It might be, instead, that we would be better off looking at a multi-faceted description of legal (for example, something closer to what Llewellyn did with his idea of 'law jobs') ${ }^{84}$ than we are focusing on a single overriding definition.

Another issue which is worthy of further exploration is the distinction between justification and coercion. I have argued that Dworkin follows Realism and helps to close the justification gap that exists in that older theory. This is important only if one believes that the justification gap problem is important and there is nothing that requires a legal theorist to believe that it is. One can simply rely on the notions of power and coercion to explain why individuals follow the law. Such a view, however, can be impoverished. Austin attempted to explain the law as a function of coercion and power and most modern jurisprudential scholars believe his theory provides a distorted view of the law. The common view now is that law is much too nuanced and complex to be explained only in terms of coercion. Law provides not only a coercive element but a facilitative one as well and legal theories need to be able to analyse these important elements. Exploring the differences between Realism and Dworkin on this important issue can provide a mechanism for the larger issue of justification within the law.

Not all problems, then, are eliminated even if we look to explore similarities between theories as opposed to differences. What we can take from this overall is the view that legal theory need not be an all or nothing thing. We need not accept wholeheartedly only one theory and argue that all others are incorrect. This is rarely accurate and usually can only be explained by mistakenly describing the theories of others. In reality, there is often far more in common between legal theories than there are differences. If we examine theories in order to properly understand those things which a theory might do well, then we are likely to be better able to explain the complex phenomenon that is law and legal systems generally. This does not mean, of course, that we can eliminate all differences between legal theories. There will still be disagreements, even on important fundamental issues. Nor does it mean we ought to give up critiquing jurisprudential theories. Of course we should not. Exploring similarities to the extent we explore differences, however, can be a more useful endeavour in at least some circumstances. Our critiques, then, ought to look at ways in which theories correspond to each other just as much as they explore ways they differ.

84 K Llewellyn, 'My Philosophy of Law' in Julius Rosenthal Foundation for General Law, Northwestern University, My Philosophy of Law: Credos of Sixteen American Scholars 1941 (Boston Law Book Co 1941) 183-97, 185-86. 
